http://artnodes.uoc.edu

\title{
The metrics of landscape Stereo fieldwork by Francisco Afonso Chaves and other Portuguese explorers
}

\author{
Victor Flores \\ Universidade Lusófona de Humanidades e Tecnologias Lisboa \\ Submission date: December 2017 \\ Accepted date: April 2018 \\ Published in: June 2018
}

\section{Recommended citation}

Flores, Victor. 2018. "The metrics of landscape. Stereo fieldwork by Francisco Afonso Chaves and other Portuguese explorers". In Pau Alsina, Ana Rodríguez and Vanina Y. Hofman (coords.). "Media Archaeology". Artnodes. No. 21: 99-108. UOC [Accessed: dd/mm/yy] http://dx.doi.org/10.7238/a.v0i21.3162.

This article is - unless indicated otherwise - covered by the Creative Commons Spain Attribution 3.0
licence. You may copy, distribute, transmit and adapt the work, provided you attribute it (authorship,
journal name, publisher) in the manner specified by the author(s) or licensor(s). The full text of the
licence can be consulted here: http://creativecommons.org/licenses/by/3.0/es/deed.en.

\section{Abstract}

Although the invention of the stereoscope in 1832 shed new light on the anomalies of vision and on the constructive role of the mind in visual perception, this became no obstacle to its scientific uses throughout the 19th and 20th centuries. On the contrary, combined with photography, the stereoscope embodied both the imperialist politics of the 19th century and its scientific ideology. These pairs of twin images perfected photography as an accurate and credible scientific instrument and gave explorers the chance to map, calculate and "grab the world in an image". The use of stereo photography in geodesic and topographic fieldworks is one of the best evidences of such scientific practices, largely overlooked by stereo photography studies. Here, we introduce the stereoviews by Portuguese explorers such as Francisco Afonso Chaves, an early-20th-century Azorean naturalist, and analyse a particular series of Verascope glass plates which represent theodolites photographed during his fieldwork. The identification of 


\section{artnodes}

http://artnodes.uoc.edu

The metrics of landscape

common uses of theodolites in the stereo collections of other explorers suggests the advantage of expanding fieldwork to the laboratory, a fact David Brewster (1856) would naturally recognise as a "rational pleasure".

\section{Keywords}

stereo photography, stereoscope, geodesy, theodolite, topographic explorer

\section{La métrica del paisaje \\ El trabajo de campo estereoscopico de Francisco Afonso Chaves y otros exploradores portugueses}

\section{Resumen}

Si bien la invención del estereoscopio en 1832 aportó nueva luz sobre las anomalías de la visión y sobre el papel constructivo de la mente en la percepción visual, esto no fue obstáculo para emplearlo en usos científicos en los siglos xix y xx. Más bien al contrario, junto con la fotografía, el estereoscopio supo expresar, por un lado, la política imperialista del siglo xix y, por otro, su ideología científica. Sus parejas de imágenes idénticas perfeccionaron la fotografía como instrumento científico preciso y creíble y ofrecieron a los exploradores la oportunidad de trazar, calcular y «atrapar el mundo en una imagen». El uso de la fotografía en estéreo en los trabajos de campo geodésicos y topográficos constituye uno de los mejores ejemplos de dichas prácticas cientificas, a menudo olvidadas a la hora de realizar estudios sobre fotografía estereoscópica. Aquí aportamos las visiones estereoscópicas de exploradores portugueses como Francisco Afonso Chaves, naturalista de principios del siglo xx nacido en las Azores, $y$ analizamos una serie concreta de placas de cristal de una cámara Verascope que muestran teodolitos fotografiados durante su trabajo de campo. El descubrimiento de usos habituales del teodolito en las colecciones estereoscópicas de otros exploradores sugiere la ventaja de poder ampliar el trabajo de campo y llevarlo al laboratorio, un hecho que David Brewster (1856) reconocería fácilmente como un «placer racional».

\section{Palabras clave}

fotografía estereoscópica, estereoscopio, geodesia, teodolito, explorador topográfico

I.

"The stereoscope not only transformed the vision of the images, but also the image of vision". Nicholas Wade (1992)

The history of the stereoscope is distinct from that of stereo photography. It is important to recall this fact since we are used to seeing them combined and presented as a unique medium. In fact, these are two inventions with distinct histories and fundamentals. Although modern science used both to better see and to display its discoveries, the truth is that the stereoscope and photography first saw vision and its contribution to knowledge from a different standpoint. To return to this fact allows us to show how, for a moment, the stereoscope shook scientific thought on vision in the 19th century, and to revive part of the forgotten tension, apparently unlikely today, between the original programmes of the stereoscope and photography, as they were felt at the time (Ellis 1856; Burgess 1869; Henderson 1871).

In the 19th century, vision, knowledge and science were almost interchangeable synonyms. The impact of positivism and observation as a scientific methodology left almost no opportunity to question the capabilities of natural perception and the accuracy and precision of the eyes. The studies on optical physiology carried out as of 1820 would challenge this consensus, claiming anomalies, flaws and illusions (!) in vision. The stereoscope was invented to show these very defects, serving as counter-evidence to all the traditional theories of vision which defended the existence of a direct correspondence between the outside world and the perceived images. That instrument was invented by Charles Wheatstone in 1832 and demonstrated that it was possible to produce a visual perception of relief from a pair of two-dimensional 


\section{artnodes}

images with different perspectives, corresponding to the points of view of the right and the left eye. This demonstration of binocular disparity was made through black and white geometric drawings without any shades or other visual signs which might contribute to the perception of relief (figure 1). This would become one of the most profound revolutions in the visual experiences of the 19th century: the act of seeing was decoupled from the object that was seen. It was even possible to perceive relief in two-dimensional images! And all this because vision could generate perceptions somehow autonomous from sensations. In other words, it was possible to argue that "what one sees is not always what is there", that vision can also be a creation of the subject, and therefore not neutral or a mere receptacle of the outside world.

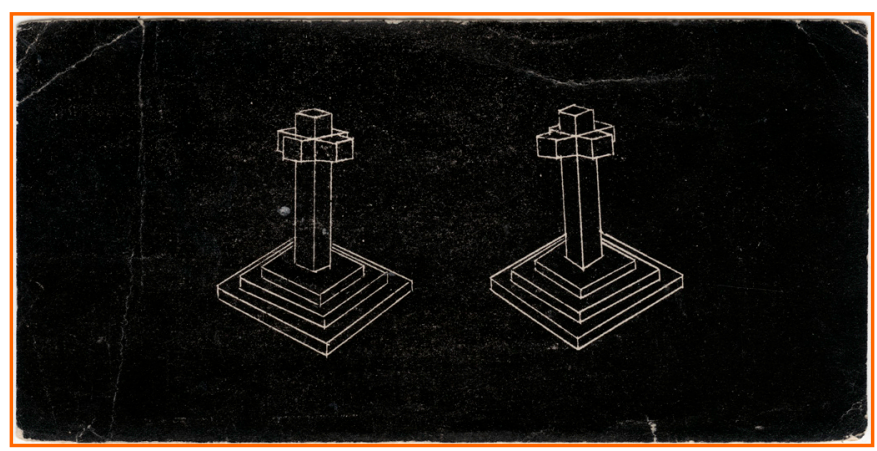

Figure 1. Stereo engraving of a cross. Author's collection.

This "subjective model" would expose unwanted instabilities in vision (Bantjes 2016), namely its ability to contradict geometric logic (there exists, for instance, a capacity for ocular accommodation of geometrically distinct lines), alerting to the constructive role of the mind and to the fact that the mind suggests a spatial perception it already knows (a phenomenon demonstrated by the pseudoscope, when the brain refuses to see concave human bodies or to invert the volume of known objects). In the 1830s and 1840s, the so-called period of "stereoscopy without photography", the stereoscope made clear that vision could deceive. However, this did not much affect positivism and its blind trust in vision, an objective vision, and it did not resist the advent of photography. Although Jules Duboscq was still publishing stereo lithographs in 1851, and in 1853 stereograms of children's toys and geometrical figures were exhibited as evidence of optical illusions (figure 2), the widespread idea was that the best use of the stereoscope could only be reached through "exact copies of nature", such as the ones provided by photography. Today, it is also consensual that "without photography, the stereoscope would have been relegated to a distant and inactive existence, even if honorable, in the world of science", or would have remained a "mere toy, reduced to a dated curiosity similar to the phenakistiscope and the kaleidoscope" (Schiavo 2003, 118). This had already been realised back then, when some authors concluded that, even though there existed no natural relationship between them, it was a "suitable marriage", in which one dignified the other (Ellis 1856, 50).

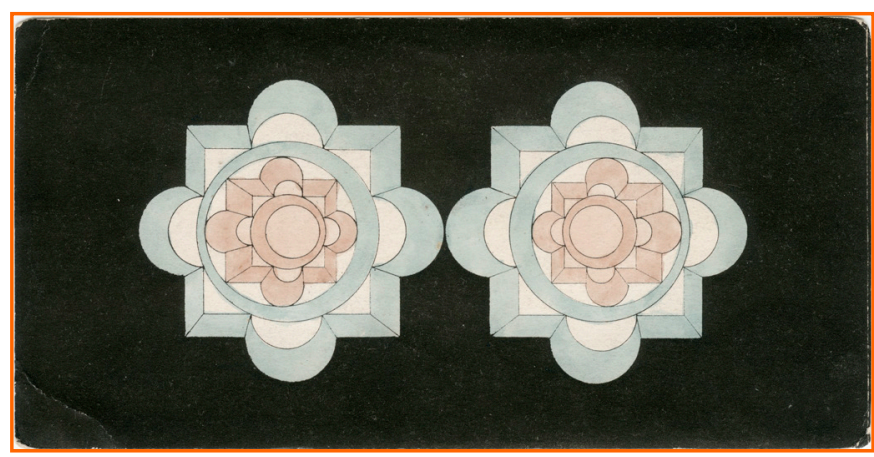

Figure 2. Stereo lithograph of a pattern receding from the viewer. Author's collection.

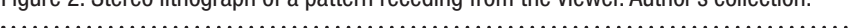

This "marriage" meant a conversion for the stereoscope. An ironic and paradoxical conversion. The instrument that served to expose the shortcomings of vision was now used to enhance and expand vision. ${ }^{1}$ Meanwhile, as concerns photography, this merging with the stereoscope strengthened its status, valued by the positivist theory of vision: the observation of the world could be prolonged, and unforeseen details could be detected (through the lenses of the stereo viewer), as François Arago had intuited in his Rapport for the public presentation of photography in 1839. In a very Cartesian way, the photographic camera is the exterior device seen as the new "innocent eye", ensuring the boundary between the human body and the image and, likewise, guaranteeing objectivity and neutrality. But it was not photography alone which was adopted by the modern scientific ideology and by the imperialist politics of the 19th century. To see the "world in an image", made accessible and available to the eye, also required the general adoption of the stereoscope. Along with photography, the stereoscope was a central instrument of that rhetoric. Both became synonyms of evidence, documentation and truth!

The contribution of the institutional apparatus to the credibility of photography and to its "status of truth" was extended to the stereoscope. Labelled by Baudelaire as a "scientific toy" whose 


\section{artnodes}

http://artnodes.uoc.edu

The metrics of landscape

oculars he scornfully compared to the "skylights of infinite", ${ }^{2}$ the stereoscope was, since its famous presentation at the Great Exhibition in London in 1851, subject to the same public and institutional "power relations" of photography. If the modern status of photography depended "on the institutions and agents who defined it and made it work" (Tagg 1988, 63), the stereoscope gained authority from the same source. In this regard, it is important to note that the discourse praising stereoscopy and its geometric and scientific precision is rooted in science itself. This is, in fact, the position of David Brewster, naturalist philosopher and inventor of the lenticular stereoscopic viewer, on which the popularisation of stereoscopy would be based. In 1856, in his book The Stereoscope. Its History, Theory and Construction, Brewster describes the advantages of the application of stereoscopy to the arts and entertainment, but also to natural history and to education, to which stereoscopy brings, he claims, a "rational pleasure".

And it was immediately in that same decade that the application of stereoscopy to Chemistry, to Physics, to Medicine and also to Astronomy and Cartography could be seen. Its first recognised advantage was the way in which it enhances observation. In other words, not only can the observation be extended and more attentive, with a better view of details, it also makes it possible to prolong the fieldwork into the laboratory. Like a simulator, the stereoscopic view recreates the relief of the landscape and its objects, allowing an immersive and strongly realistic observation... in the distance. Meanwhile, stereoscopy turned out to be very important to Astronomy, by restoring the three-dimensionality of the moon, the stars and even the sun, whose distances show us inevitably flat images, and whose relief had never been seen before. In fact, the telescopic stereoviews by Warren de la Rue still reveal to us the 'unseen', that is, the volume of celestial bodies, impossible to contemplate except in stereoscopy. ${ }^{3}$ Furthermore, in medical diagnosis, its use was fundamental to photomicrography, revealing the three-dimensionality of minuscule creatures (Moitessier 1866), or to X-rays, offering us more precise details of the human body. ${ }^{4}$ As from 1900, stereoscopy was used in the therapeutic field, specifically in orthoptics, for the correction of strabismus and amblyopia (card sets by Kroll, Javal, Wells, Dahfeld). This use not only recalls the original programme of the stereoscope, but also links the device with the idea of a "correct vision", a "good vision".

This connotation of the stereoscope as offering correct and accurate vision was parallel to the idea of stereoscopy enabling geometric and mathematical precision, which thus could be used to calculate and measure space. It was this idea that led the French geodesic and military engineer Aimé Laussedat (1818-1907) to make the first photogrammetric survey in 1849. His invention consisted of using photography to do what he had already tested with the camera lucida, which he called "iconometry": to compare and measure differences and respective three-dimensional coordinates from two views of the same point with slightly different angles. Terrestrial photogrammetry - a name coined later by the German architect Albrecht Meydenbauer - brought the stereoscopic procedure to geodesic and topographic studies, as well as to building and monument measuring, areas in which it is still used today. It was followed by the phototheodolite, that is, by the combination of these photographs with the theodolite, an optical precision instrument used to measure horizontal and vertical angles since at least the 17 th century. Photography added more descriptive information to theodolite measurements and subsequently provided relief views. This is the origin of the expression 'true relief', frequently used in texts about stereoscopy then published in the Portuguese and international press, but also in slogans of advertisements for stereoscopic cameras with iconometric viewers and telemeter function.

The integration of stereoscopy in scientific practice also depended most importantly on a rhetoric about image accuracy and preciseness. This is present in the enthusiastic texts by Oliver W. Holmes (Holmes 1859; 1861), but also, on another level, in the publicity for stereoscopic cameras after 1900. The Verascope camera advertisements by the French company Jules Richard, many of them published in Portugal in the early 20th century in the Boletim Photographico and in the Echo Photographico, are some of the advocates of this rhetoric: "The Verascope is the ideal device. It is the real image, corresponding to nature both in size and in relief. It is the most accurate document" (figure 3). This intensive promotion of stereoscopic photography was very relevant in the beginning of the 20th century, stimulating a rebirth of the 'stereo craze' which had waned across Europe since 1880. In fact, this is a key period for Portuguese stereoscopy. Some of the most important editions of stereoviews in Portugal date from this period: the Estereoscopio Portuguez by Aurélio Paz dos Reis, the 'Stereo' Ideal by Daniel Augusto Bento, both from Oporto, the collection Estereoscópio - Assumptos Portuguezes, by Justino de Carvalho (Gaia), as well as others by Francisco Borges, Jorge de Almeida Lima and José de Menezes e Almeida. As these titles show,

2. We are referring to two important texts by Charles Baudelaire including critiques of photography and specifically of the stereoscope: The Philosophy of Toys (or. La morale du joujou, Le Monde littéraire, 17 April 1853) and The Modern Public and Photography (or. Le public moderne et la photographie, Salon de 1859, 0Euvres complètes, éd. Claude Pichois, Paris, Gallimard, 1962, t. II.).

3. One of the applications of stereoscopy in Astronomy, still important today, is to identify the position of asteroids. A pair of stereoscopic images placed in a viewer or 'stereo-comparer' presents the relief of any slightly displaced celestial body.

4. For a more detailed reading of these applications of stereoscopy to science: Peres (2015). 


\section{artnodes}

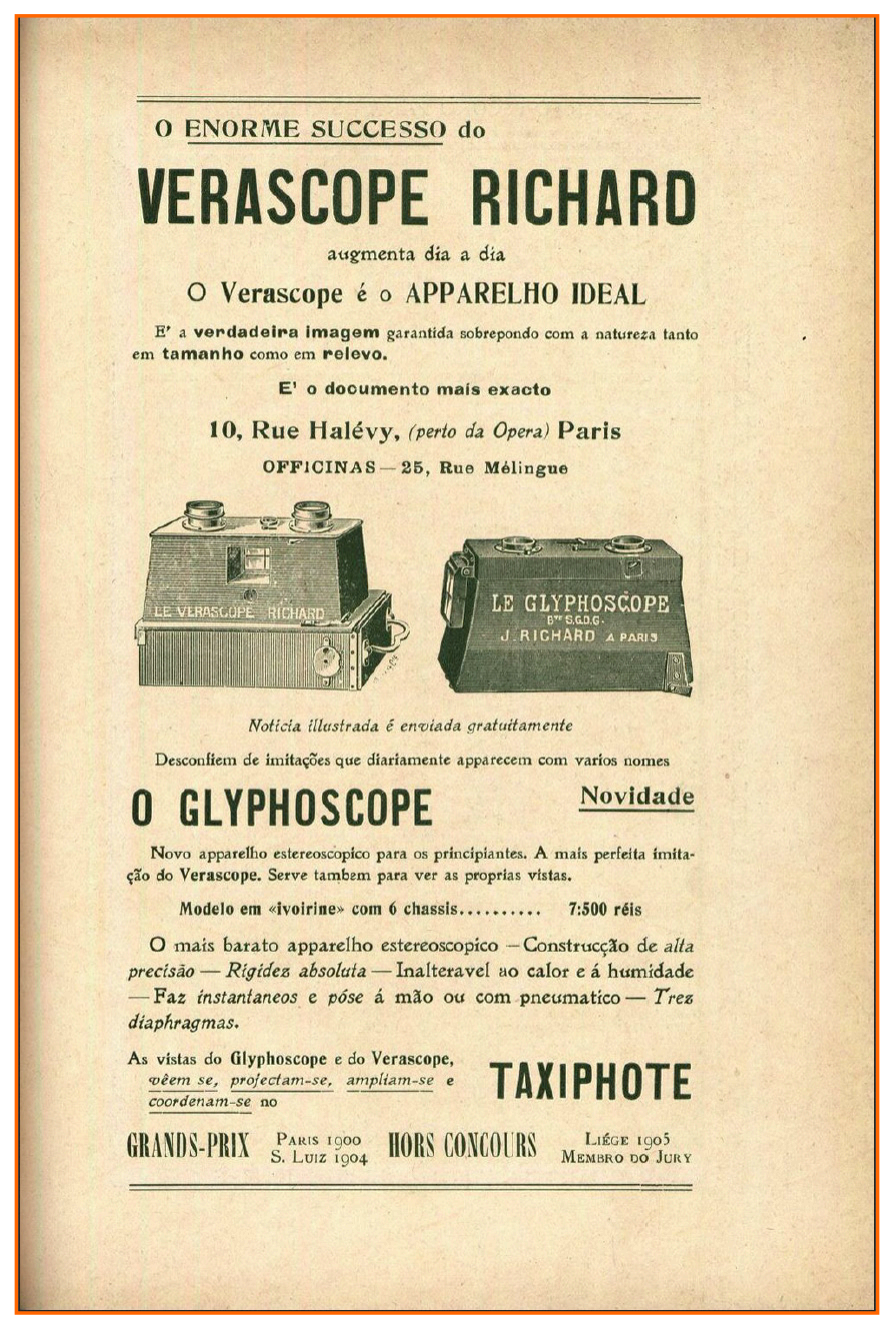

Figure 3. A Jules Richard ad published in Portugal in 1906 promoting the Verascope camera as the ideal device for producing the most accurate documents.

Portugal was the main theme of the Portuguese stereoviews, with stereo cameras covering the country from north to south, including the islands. The cities and their monuments, the washerwomen, the countryside and its people were the themes not only of Portuguese stereoviews but also of foreign companies (Keystone, Underwood \& Underwood) which sent their photographers to Portugal. Along with all this production which supplied the bourgeois parlours and set the photographic taste of this period, mention must be made of all the contemporary amateur production that we can now discover in Portuguese archives and museums (Arthur Benarus, Arthur Freire, Adelino Furtado, among others) and which used the verascope camera to portray not only tours but also current affairs: the floods of the Douro in 1909, Republic Day and important official visits. Because it was lighter and more portable thanks to its $4.5 \times 10.7 \mathrm{~cm}$ format, the versacope made stereoscopic photography a synonym for instantaneousness and even for a certain photographic freedom, being practical for travelling and therefore useful for science and scientific fieldwork.

II.

\begin{abstract}
"Maybe there is no industry or science where photography has no place. Unlike us, our children will see it applied to geometry, to geology, to metallurgy, to meteorology, to surveying, to astronomy, to physics, to botany, to chemistry, to mineralogy, to zoology, to mining and even to military science. Whenever a general lacks time to determine an exact position he will be spared that inconvenience by the instantaneity and fidelity of the photographic reproduction".
\end{abstract}

(Disdèri 1855, 33)

Little is known about the scientific use of stereoscopic photography in Portugal as it has not been widely studied. The study of the photographic archive of Francisco Afonso Chaves (1857-1926), naturalist and army Colonel, mostly made up of stereoscopic photographs, is thus a great opportunity to retrace his scientific work and the role played by this photographic process. One of the most relevant of the extensive achievements of Afonso Chaves is his establishment of the Azorean Meteorological Service in $1901,{ }^{5}$ of which he was the first director. This service carried out meteorological and geodesic observation of the Azores and was tasked with sending meteorological data to Lisbon and to the European observatories through the submarine cable built a few years previously, in $1893 .{ }^{6}$ Together with Prince Albert I of Monaco, Afonso Chaves undertook the project for the creation of an international meteorological service incorporating a net of stations in the Azores, believing that the atmospheric variations of the North Atlantic had a considerable effect on the climate of continental Europe.

In Afonso Chaves' collection, housed at the Museu Carlos Machado, on the island of Ponta Delgada in the Azores, there are several hundred stereoscopic views of these islands, made between 1901 and 1905, immediately after the creation of the Azorean Meteorological Service. Among these diversified views of the coastlines, of waterfalls from cliffs, of caves, of anchored boats, of islets and imposing rocks, more than two dozen very similar photographs with the same object appear

5. The Meteorological Service of the Azores ceased to exist in 1946 and was replaced by the National Meteorological Service, the predecessor of the existing Portuguese Institute for the Sea and the Atmosphere.

6. The submarine cable plays another important role in the scientific work of Afonso Chaves, as it allows him to follow the ruptures (for instance in 1902 between São Miguel and Carcavelos or between Angra and the island of Pico) to gather submarine information (temperature, depth) provided by the maintenance ships and by the company Europe \& Azores Telegraph. The removed parts of the damaged cable allowed him, for instance, to detect the corrosion caused by contact with thermal springs (rich in corrosive acids). Cf Chaves 1960. 


\section{artnodes}

http://artnodes.uoc.edu

The metrics of landscape

repeatedly and at irregular intervals. They represent a theodolite under a parasol in a natural landscape (figure 4). Because these images are spread out through the digital catalogue between scenes of recreational activities, traditions and festive celebrations, they tend to seem displaced and to look austere. Above all they represent bleak and empty spaces, sometimes hard or even dangerous to access (figure 5). Most of the times, the box of the theodolite is next to the tripod and in, some cases, Afonso Chaves placed over it the leather case of his verascope camera and his field notebook (figure 6). Sometimes distant, almost lost in the landscape, sometimes in the foreground, the protagonist of these images is undoubtedly this piece of technical equipment. This impression seems inevitable when, for instance, one observes the low-angle shot taken by Afonso Chaves at the lake of Caldeira do Santo Cristo, in São Jorge (figure 7).

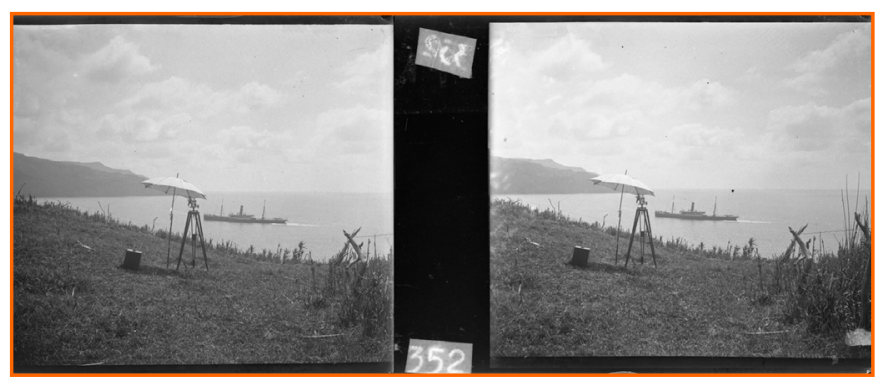

Figure 4. Francisco Afonso Chaves, Untitled stereoview, 14 August 1902. Museu Carlos Machado.

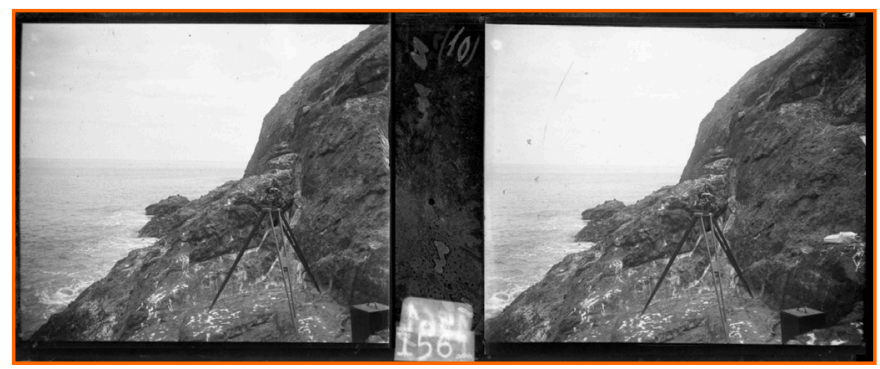

Figure 5. Francisco Afonso Chaves, Little Island of Cabras - Terceira, 11 May 1905. Museu Carlos Machado.

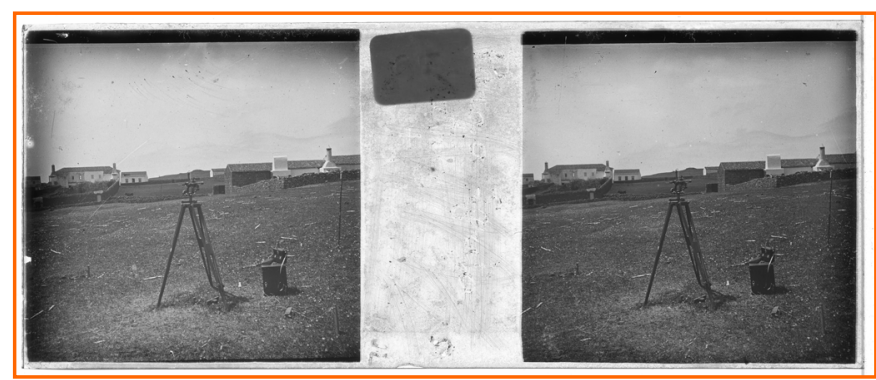

Figure 6. Francisco Afonso Chaves, Magnetic station at Cerrado da Lomba - Santa Maria 1902. Museu Carlos Machado.

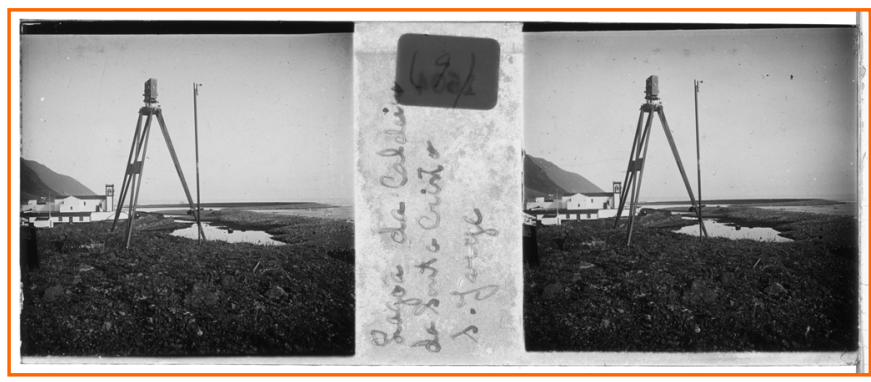

Figure 7. Francisco Afonso Chaves, Top of Lagoa Pequena at Caldeira do Santo Cristo, São Jorge. 24 June 1905. Museu Carlos Machado.

This particular set of images is not just about landscape. These are images of a 'technical set', as Gilbert Simondon (Simondon 1969) would say. Theodolite, stereoscopic camera and landscape are the means and the scientific work environment of Afonso Chaves depicted by these images. Looking at them, we can see that they show different islands (São Miguel, Santa Maria, Flores, Terceira, São Jorge, Faial) visited at intervals of one or two months in 1902, or less frequently until 1905. As a rule, Afonso Chaves didn't take more than one or two of these photographs in the same place. But their recurrence and distinctiveness show us that they are not simple records of scientific fieldwork but an integral part of this fieldwork. It is well known that images are not limited to the visible. These images are a particularly good example of this, mainly because they imply specialist historical knowledge. What do they represent? How did they add to the work carried out? We collected some elements that may contribute to this interpretation.

These stereoscopic views of the Azores between 1901 and 1905 point to a geodesic study of the archipelago, possibly related to the then recently established Azorean Meteorological Service. Their systematic nature points to a specific mission carried out by a small team which is occasionally photographed (figure 8). With these pictures, Afonso Chaves might be visually registering the location of the theodolite. On some of these stereoscopic views there are notes of geographic coordinates, such as 'Taken from the E' (figure 9), which suggests that this was an important function of the picture.

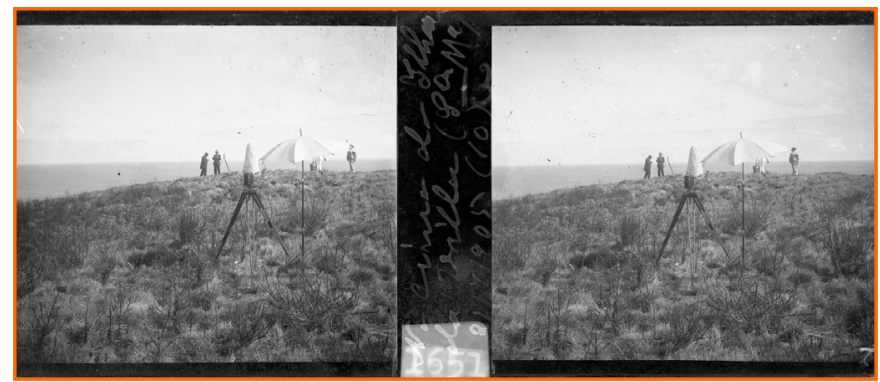

Figure 8. Francisco Afonso Chaves, Top of islet of Vila do Porto, Santa Maria, 21 July 1905. Museu Carlos Machado. 


\section{artnodes}

http://artnodes.uoc.edu

The metrics of landscape

Another feature of some of these pictures is the reverse shot of the theodolite, a kind of $360^{\circ}$ view to estimate the perpendicular between the images, or just to accurately locate the position of the device. While the theodolite allowed Chaves to measure some distances, it was then necessary to register the latitude and longitude of the areas. This georeferencing could be performed through the transposition of coordinates of known points (such as survey markers), a method widely used between 1850 and 1900 .

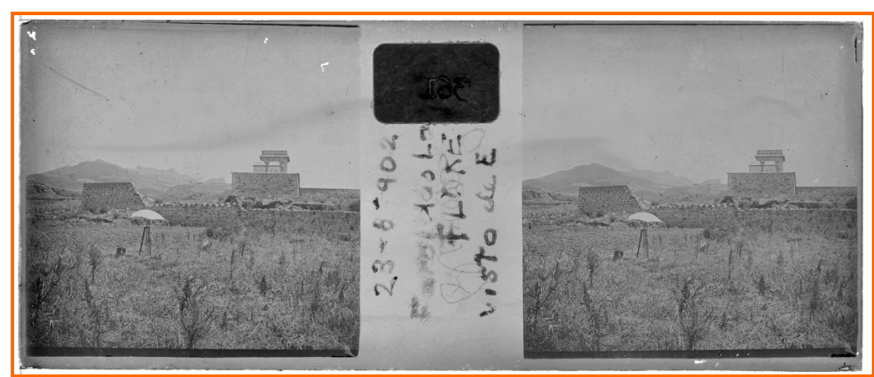

Figure 9. Francisco Afonso Chaves, Lages lighthouse, seen from East, Flores, 22 Augus 1902. Museu Carlos Machado.

As mentioned above, the association of the theodolite with stereoscopy dates back to the mid-19th century. However, these stereoviews by Afonso Chaves are not phototheodolites, although they seem to fulfil the same purpose. These photographs both located the measured land and gave information about its shapes, relief and orographic distances. In other words, they allowed the fieldwork to continue in the laboratory. Curiously, being part of an archive mostly made of negatives, these pictures are distinctive because they are almost all positives, thus showing that they were effectively used.

This was therefore the moment when geodesic studies could no longer do without photography. In this same period, other Portuguese scientists adopted stereoscopic photography to document their missions, specifically in Africa. Admiral Gago Coutinho (1869-1959) used an 8x18 stereoscopic camera in his mission for the Delimitation of the Southern Frontier of the Zambeze, between 1904 and 1906, in his Geodesic Mission of East Africa, between 1907 and 1910, and even later, between 1912 and 1914, in his mission for the Delimitation of the Southeastern Frontier of Angola. A considerable number of these stereoscopic views also include theodolites on the ground, often next to survey markers, including in their captions geographic references (figures 10 and 11). In other pictures the focus is placed on the scientist in a celebratory portrait of him interacting with the scientific device. This is the case of a stereoview taken in the Geodesic Mission of East Africa, which separately portrays Gago Coutinho and Sacadura Cabral (1881-1924) in the right and the left view. ${ }^{7}$ These portraits present the two explorers levelling the theodolite with exactly the same body posture, the same scenic elements and even the same onlookers standing still as statues (figure 12). And this good-humoured experiment works! On the stereo viewer both pictures merge into one, and so do the two explorers!

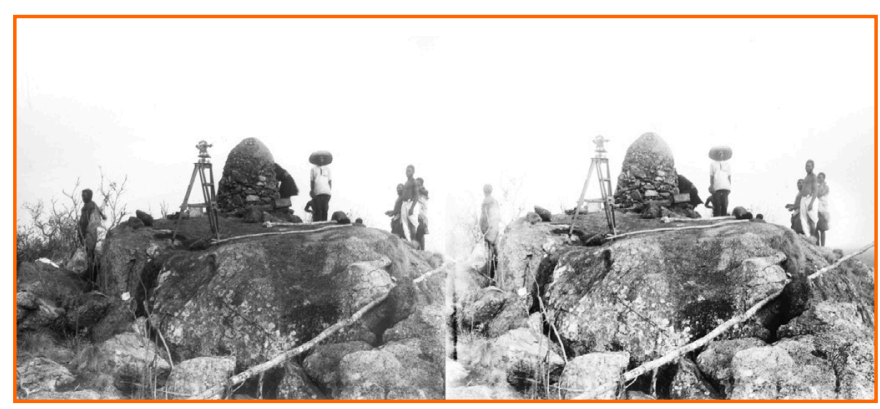

Figure 10. Gago Coutinho, Mission for the Delimitation of the Southern Frontier of the Zambeze [1904-1906] Marker XV—Ichefissi (View from the W), University of Lisbon, Instituto de Investigação Científica Tropical.

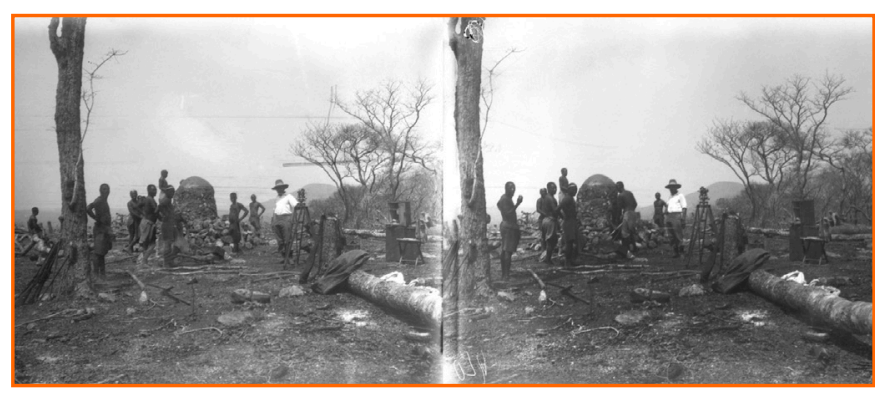

Figure 11. Gago Coutinho, Mission for the Delimitation of the Southern Frontier of the Zambeze [1904-1906] Marker X-Fingúê (View from the W), University of Lisbon, Instituto de Investigação Científica Tropical.

.............................................................

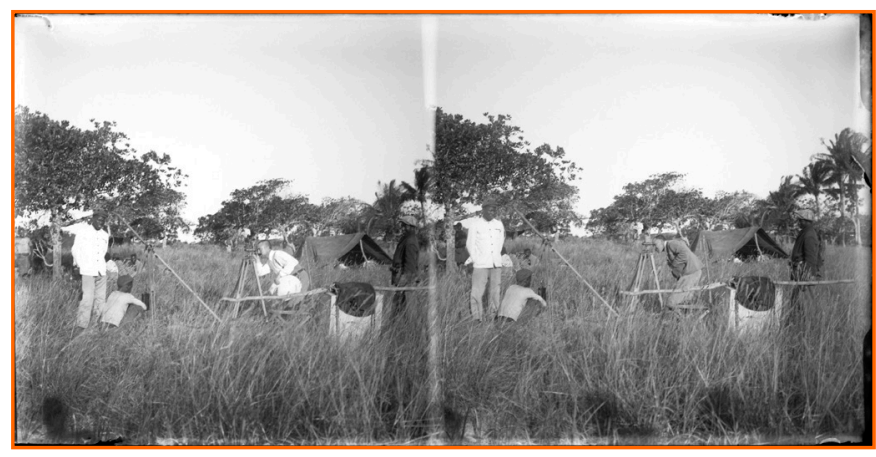

Figure 12. Gago Coutinho, Geodesic Mission of East Africa [1907-1910]. Stereoview with Gago Coutinho and Sacadura Cabral levelling, University of Lisbon, Instituto de Investigação Científica Tropical.

7. Although these two explorers participated together in several adventurous missions in Africa, Carlos Gago Coutinho and Artur de Sacadura Cabral became better known for the first air crossing of the South Atlantic in 1922. 


\section{artnodes}

http://artnodes.uoc.edu

The metrics of landscape

Among the Portuguese missions in Africa we may also mention the example of the stereoscopic photographs by Rear Admiral César A. Moura Brás (1881-1954). In his mission for the Delimitation of the Luso-Belgian Frontier between Angola and Congo, between 1914 and 1915, stereoscopic photographs also follow the construction of boundary stones, as well as delimitation works with theodolites. Figure 13 is one of the most paradigmatic of this work, not only because of the unusual number of tripods placed diagonally on the ground (a real scientific arsenal!), but also because of the impact these works are having on the local community. Reams of paper coming out of a folder are prominent in the centre of the image, discreetly denouncing the herculean size of the task!

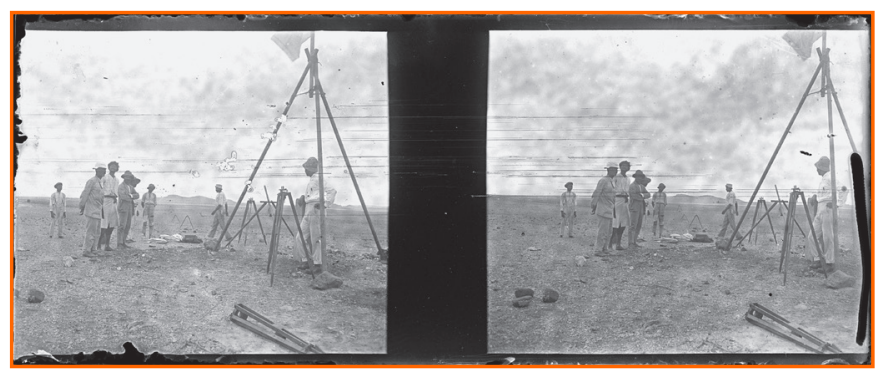

Figure 13. César Augusto Moura Braz, Mission for the Delimitation of the Luso-Belgian Frontier between Angola and Congo (1914-15): Delimitation Works with Theodolite. Centro Português de Fotografia, DGLAB.

The last pictures of the Azores taken by Afonso Chaves in this period have a different purpose. They no longer represent the landscape, but the atmosphere. The series of stereoviews captioned as 'Probe Balloon over Ponta Delgada. Convent of Graça', includes fourteen pictures depicting the launch of a probe balloon on the 22nd of August 1905 (plates 9 to 21 in the archive). The sequence begins with the balloon being filled in a church cloister before it rises and completely disappears in the skies of the island (figures 14 and 15). Among these pictures, one stands out which shows a theodolite pointing to the sky, being handled on a high terrace (figure 16). The almost cinematographic sequence of these stereoviews punctuates the balloon's course step by step. It is followed by the theodolite to measure its progressive location and, in this way, to obtain the values of the wind speed. Afonso Chaves' camera pursues the balloon as an event, certainly a scientific one, but not without evoking the early uses of balloons by photographers such as Nadar. As it moves away, the balloon loses the stereoscopic effect and becomes a small, flat form, just like the moon before the stereoscopic photographs by Warren de la Rue.

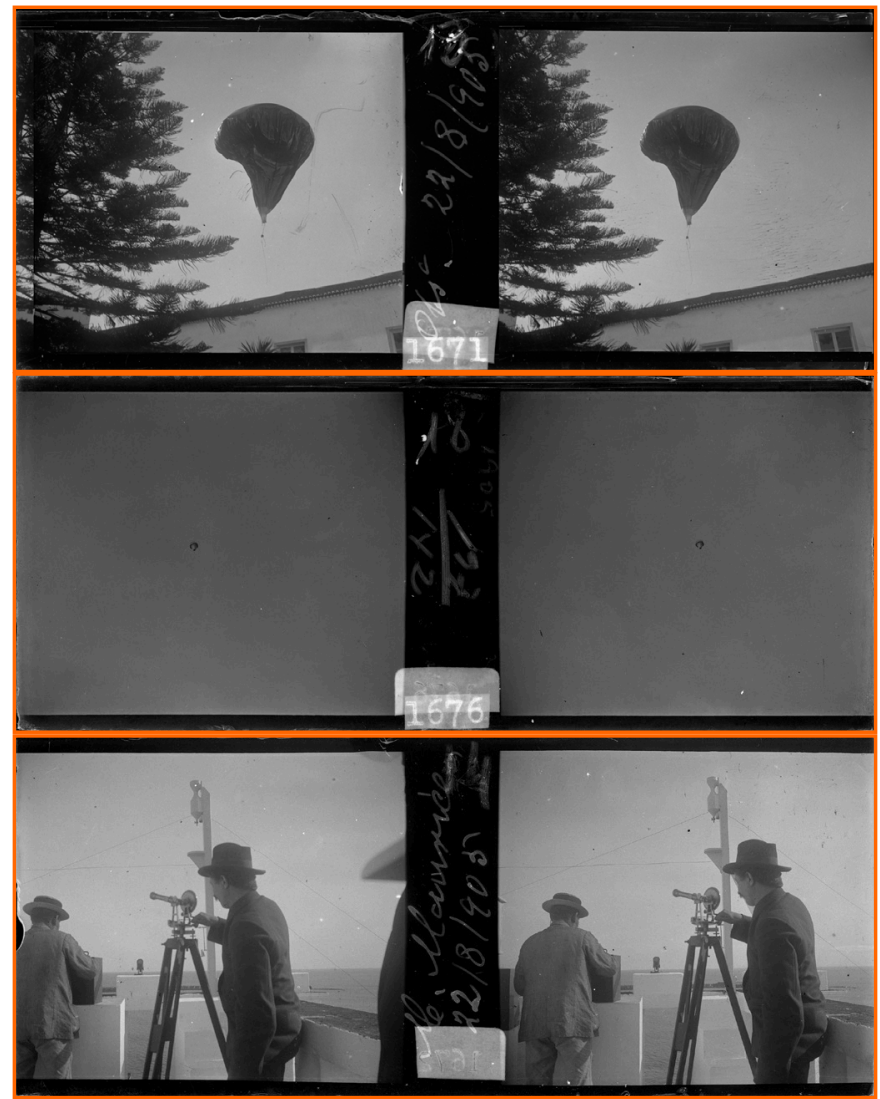

Figures 14, 15 and 16. Francisco Afonso Chaves, Ascension of the balloon-probe at the Observatory of Graça, Ponta Delgada, S. Miguel, 2 August 1905. Museu Carlos Machado.

\section{III.}

The verascope views by Afonso Chaves signal the crucial role stereo photography played in Portuguese topographic surveys. Combined with the theodolite, stereo photography became a tool for the measurement of territories and for the analysis of their reliefs. This hybrid medium was particularly useful for the Azorean mountainous islands: the location of hills, peaks and slopes required precise map representations, impossible to achieve with the traditional plane table technique. This relationship between topographic relief and the use of stereo photography in Portuguese geodesic surveys, specifically in Africa, has not been studied. 'Topophotography' (as it has been known in Portugal since the 19th century) was used by the most renowned Portuguese surveyors to map Africa after the creation of the Pink Map (1884-1885). The Portuguese claim of sovereignty over the territories between Mozambique and Angola demanded a thorough measurement and delimitation of the frontiers so that effective governance could be claimed. Large stereo photography collections from the Portuguese colonial surveys are still sitting in the tropical archives, waiting for the most relevant moments of Portuguese scientific visual culture to be disclosed. Although not created for entertainment like most touristic stereocards sold at the time, these 


\section{artnodes}

http://artnodes.uoc.edu

scientific views (although complex and demanding an expert eye!) bring us back the 'rational pleasure' that fuelled these surveys.

\section{References}

Bantjes, Rod. 2016. "Hacking Stereoscopic Vision: The NineteenthCentury Culture of Critical Inquiry in Stereoscope Use". The International Journal of Film and Media Arts. Vol. 1 No. 2 Stereoscopic and Immersive Media: 4-21.

Burgess, N. G. 1862. The Photograph Manual; A Practical Treatise, Containing the Cartes De Visite Process, and the Method of Taking Stereoscopic Pictures. New York: D. Appleton \& Co.

Brewster, David. 1856. The Stereoscope. Its History, Theory and Construction, With its Application to the Fine and Useful Arts and to Education. London: John Murray.

Chaves, Francisco Afonso.1960. "Erupções submarinas nos Açôres. Informações que os navegantes podem prestar sobre tal assunto". Açoreana No. 5, Vol. V. Angra: Tipografia Andrade.

Chaves, Francisco Afonso. 1909. "Gisements de Diatomées fossiles à Furnas (lle de S. Miguel). In Bulletin de la Société Portugaise des Sciences Naturelles". Tome II, fasc. 3 (May).

Disdèri,A.A. E. 1855. Renseignements photographiques indispensables à tous. Paris.

Ellis, J. 1856. Progress of Photography, Collodium, the Stereoscope. London: Bell and Daddy.

Henderson, J. 1871. "Photography and the Stereoscope”. Anthony's Photographic Bulletin 2, no. 6.

Holmes, Oliver W. 1859. "The Stereoscope and the Stereograph". The Atlantic Monthly, vol. 3, 20, June: 738-749.
The metrics of landscape

Holmes, 0. W. 1861. "Sun-Painting and Sun-Sculpture. With a Stereoscopic trip across the Atlantic". The Atlantic Monthly, vol. 8: 13-29.

Moitessier, A. 1866. La photographie appliquée aux recherches micrographiques. Paris: J. B. Baillière.

Peres, Marília. 2015. "Aplicações da fotografia estereoscópica às ciências: uma perspectiva histórica”. Stereo \& Immersive Media. Proceedings 2015, Lisbon: Edições Universitárias Lusófonas.

Schiavo, Laura B. 2003. "From Phantom Image to Perfect Vision: Physiological Optics, Commercial Photography, and the Popularization of the Stereoscope". In Lisa Gitelman and Geoffrey B. Pingree (eds.). New Media, 1740_1915, Cambridge, Mass.: The MIT Press.

Simondon, Gilbert. 1969. Du mode d'existence des objets techniques. Paris: Aubier-Montaigne.

Tagg, John. 1988. The Burden of Representation. Essays on Photographies and Histories. Minneapolis: Univ. of Minnesota Press. https://doi.org/10.1007/978-1-349-19355-4.

Wade, Nicholas. 1992. "Mirror stereoscope". Perception, Vol. 21, Supplement 1: Faces of Psychology. London: Pion Limited.

\section{Acknowledgements}

Army Geospatial Information Centre; Portuguese Centre of Photography; University of Lisbon, Instituto de Investigação Científica Tropical, DGLAB.

Marília Peres; Gil Estevez; Maria Teresa Mendes Flores. 


\section{artnodes}

http://artnodes.uoc.edu

The metrics of landscape

CV

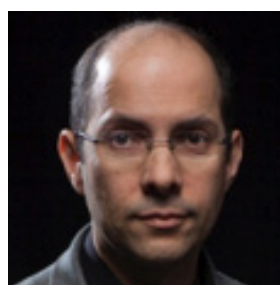

Victor Flores

Universidade Lusófona de Humanidades e Tecnologias Lisboa

victormeflores@gmail.com

Campo Grande 376, 1749-024

Lisbon, Portugal

Victor Flores is an Associate Professor at Universidade Lusófona de Humanidades e Tecnologias, Lisbon, and a visual media researcher at The Centre for Research in Applied Communication, Culture, and New Technologies (CICANT). He is the founding organiser of the International Conference on Stereo \& Immersive Media: Photography and Sound Research, and since January 2017 has been the principal editor of the corresponding International Journal on Stereo \& Immersive Media (http://revistas.ulusofona.pt/index.php/stereo). He coordinated the scientific research project "Stereo Visual Culture. The Visual Culture of Portuguese Stereoscopic Photography" funded by the Portuguese National Foundation for Science and Technology (2012-15). He received his Ph.D. in Communication Sciences from Universidade Nova de Lisboa in 2009 and he currently lectures on graduate and postgraduate courses in photography, visual culture, image analysis and media arts. He recently edited the book The Third Image. Stereoscopic Photography in Portugal (Short Digital Version, 2016, Documenta), and has previously published books such as The Technical Images and their Beliefs (Vega, 2012) and Minimalism and Post-Minimalism: Form, Anti-Form and Body in the Work of Robert Morris (Labcom, 2007). Since 2015 he has curated several exhibitions dedicated to stereoscopic photography. 